\title{
Entrevista - Pe. Georg Lachnitt
}

\author{
Eva Maria Luiz Ferreira ${ }^{1}$ \\ José Francisco Sarmento Nogueira ${ }^{1}$ \\ Leandro Skowronski ${ }^{1}$ \\ Lenir Gomes Ximenes ${ }^{1}$
}

DOI: http://dx.doi.org/10.20435/tellus.v20i41.693

\section{SOBRE PE. GEORG LACHNITT}

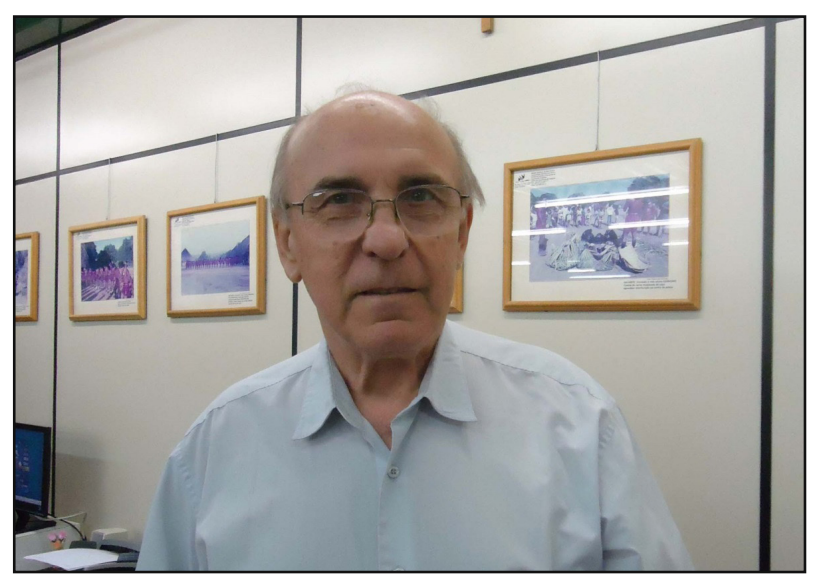

Disponível em: http://www.missaosalesiana.org.br/o-retrato-de-um-missionario-salesiano/

Missionário salesiano, nascido em 3 de abril, na cidade de Markrode, Silésia, Alemanha, no ano de 1939, sendo naturalizado brasileiro no ano de 1976. Realizou os trabalhos com os Xavante entre os anos de 1972 e 1986. Em 1987, desenvolveu pesquisas para produção de dicionário e gramática Xavante e material didático em língua indígena para as escolas indígenas. Foi diretor do Centro de Documentação Indígena (CDI) e do Núcleo de Estudos e Pesquisas das Populações Indígenas, ambos localizados na Universidade Católica Dom Bosco. Faleceu na cidade de Campo Grande, Mato Grosso do Sul, em 20 de abril de 2020.

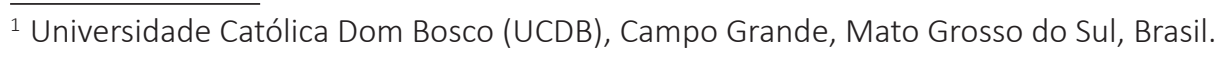




\section{A ENTREVISTA}

Há algum tempo que a equipe de pesquisadores do Núcleo de Estudos e Pesquisas das Populações Indígenas (NEPPI) ${ }^{2}$ ensaiava um convite ao nosso diretor, Pe. Georg Lachnitt, para nos conceder uma entrevista. Com ele sempre avesso às "formalidades", sabíamos que não seria uma tarefa fácil.

Padre Georg sempre gostou de nos contar suas histórias junto aos povos Xavante e Bororo. Quando tinha tempo, "vinham" narrativas acumuladas ao longo de quase 50 anos dedicados a esses povos. As viagens de Campo Grande até Sangradouro e Meruri eram recheadas de bons relatos, puxados das lembranças que cada curva provocara em sua memória brilhante, adocicada por um gosto forte de contar causos - tendo como trilha sonora as marchas sinfônicas tocadas pelos bombeiros civis alemães. "É para não cair no sono", costumava dizer Georg, antes de aumentar ainda mais o volume.

No fim de julho do ano passado, fizemos o convite para um bate-papo e, para a nossa surpresa, o aceite foi imediato. Então, no dia 12 de agosto de 2019, conversamos em uma sala de aula no segundo andar do prédio anexo à Biblioteca da Universidade Católica Dom Bosco (UCDB), em Campo Grande, MS.

Pe. Georg faleceu no dia 20 de abril de 2020, antes que esta entrevista fosse publicada. Na conversa a seguir, que partilhamos com os leitores da TELLUS, tivemos o prazer de saber mais sobre esta figura tão marcante e especial, que muito contribuiu no trabalho dos salesianos junto aos povos Xavante e Bororo.

Entrevistadores: Pe. Georg, fale um pouco de sua vida até a chegada ao Brasil.

Pe. Georg: Na verdade, eu nasci na Silésia, na Alemanha. É uma região vizinha à Polônia, dois quilômetros da fronteira, e do outro lado estava a Checoslováquia. Passou a Guerra Mundial por cima de nós, e os russos também passaram por nós, mas, como não havia homens adultos e não havia as mulheres trabalhadeiras, então não tivemos amolação com eles. Mas a amolação veio em 1946. Nasci em 1939, então, em 1946 eu tinha sete anos, aí veio o problema: chegaram os soldados

\footnotetext{
${ }^{2}$ Núcleo de Estudos e Pesquisas das Populações Indígenas, criado no dia 5 de maio de 1995, na Universidade Católica Dom Bosco, com a finalidade de coordenar os estudos e as pesquisas relacionadas às populações indígenas, implementando políticas que contribuem para o fortalecimento da cidadania dos povos indígenas e o reconhecimento de suas diferenças étnicas.
} 
poloneses - e depois eu soube, pela história, por ordem dos grandes mandatários, Churchill, Stalin, que haviam decidido evacuar uma faixa da Alemanha, vizinha à Polônia, para dar lugar aos poloneses evacuados do oriente da Polônia. E nós fomos, assim, jogados, despejados, 1.300 .000 pessoas. Nós mesmos fomos num vagão de transporte de gado, 120 vagões, 40, 50 pessoas dentro de um vagão, e aí foram dias a fio. Depois dessa deportação, fomos jogados no norte da Alemanha, Baixa Saxônia, a nossa terra passou para a Polônia geográfica, mas os que hoje estão lá também querem voltar para a terra deles, não só nós, mas é irrevogável esse fato. Então, fomos jogados lá no povoado de 2.000 habitantes, sob o comando dos ingleses, e "se arrumem...". Como, depois de três dias, a temperatura ainda perto de 0 graus, ainda estávamos na praça, os militares resolveram: "Em cima do caminhão, todo mundo". De casa em casa, [diziam] "Você fica aqui, você fica aqui", então nos colocaram em uma casa com grandes problemas de comunicação. O primeiro problema, a língua; eles falavam o baixo alemão, e nós falávamos nosso dialeto da Silésia. O baixo alemão é mais inglês do que alemão e com isso, naturalmente, a comunicação era um problema, pela língua. Pela religião, nós católicos de bater o pé e eles protestantes, luteranos de bater o pé também, tanto que na escola, no primário, não podíamos falar com os protestantes nem eles conosco, na aula, e o professor nos tratava a distância. Bom, isso foi até 1953, quando achei um colega, irmão do meu futuro cunhado. Ele, como eu, gostava de ajudar os padres na igreja, e me convidou para ir ao seminário. Bom, a mãe não gostou muito, porque [tinha] três filhos, nosso pai faleceu na guerra, outro drama. E aí fui para o sul da Alemanha, na Baviera, outra língua, e o diretor do colégio salesiano logo me disse: "Meu amigo, aprenda nossa língua para se livrar de aborrecimentos". Uma língua falada, não escrita. Lá fiquei de 1953 a 1957, quando decidi, por simpatia aos salesianos, entrar na congregação salesiana, e fiz o noviciado na Alemanha. E, no fim do noviciado, eram os últimos dez dias de retiro, entrou a nova turma, e com eles estava o Rodolfo, o Rodolfo Lunkenbein ${ }^{3}$.

\footnotetext{
${ }^{3}$ Missionário salesiano, nasceu em $1^{\circ}$ de abril de 1939, em Döringstadt, na Alemanha, pouco antes do início da Segunda Guerra Mundial. Chegou ao Brasil como missionário, fez o noviciado em São Paulo e o pós-noviciado em Campo Grande, sendo designado para a experiência do tirocínio em Meruri, local onde permaneceu até 1965. Voltou à Alemanha para estudar Teologia e outros cursos que facilitassem a continuação de sua Missão no Brasil. Ordenado sacerdote em 29 de junho de 1969, pôde voltar a Meruri, onde foi recebido com muito carinho pelos Bororo, que lhe deram o nome de Koge Ekureu (Peixe Dourado). Pe. Rodolfo participou da fundação do
} 
Ele ficou sabendo que eu ia para o Brasil, que o inspetor era do Brasil, Padre João Greiner $^{4}$. Então as tratativas foram meio puxadas, mas ele conseguiu ser admitido no noviciado aqui no Brasil, e assim nós viemos juntos. Embarcamos no navio dia 30 de outubro de 1958, no qual ficamos até 11 de novembro; chegamos a Santos, uns dois mil passageiros, sete andares, daqueles grandes transatlânticos. E assim chegamos ao Brasil e, depois de um dia de descanso, o próprio inspetor Padre Greiner, que veio ser inspetor aqui, nos levou de Noroeste ${ }^{5}$, de maria-fumaça, de São Paulo por Bauru, até Campo Grande. Quinta-feira, meio-dia, até sábado, meio-dia. Naquele tempo, o Colégio Dom Bosco estava fora da cidade, vizinho à estação ferroviária, era Campo Grande. E assim eu cheguei aqui ao Brasil.

Entrevistadores: Chegando ao Brasil, para onde o Sr. foi e quais atividades desenvolveu?

Pe. Georg: Chegamos a Campo Grande, Lagoa da Cruz, por cima, pelo cruzeiro. Essa Av. Tamandaré ainda não havia aqui. Bom, chegamos a Lagoa da Cruz com o professor Padre Walter Bocchi ${ }^{6}$, ele era nosso professor de Filosofia; nossa turma era internacional, tinha alemães, tinha mexicanos, tinha italianos, tinha espanhóis, então éramos uma turma internacional, mas todos com o objetivo de aprender português, e quase não havia brasileiros. Em março, começamos as aulas de Filosofia, 1959, 1960 e 1961. Em 1962, fui mandado por um ano para Lucélia, SP,

Conselho Indigenista Missionário (CIMI), em 1972. Lutou pela demarcação da reserva de Meruri, conquistada no ano de sua morte - em 1976.

${ }^{4}$ Nascido no dia 7 de março de 1905 em Hiltersried, Baviera, Alemanha. Em 1922, entrou no noviciado recém-criado e professou no Dia da Imaculada Conceição, Mãe de Deus. Pouco depois, colocou-se à disposição do trabalho missionário no Brasil. Em Corumbá, estudou Filosofia e, em Crocetta, Turim, Itália, estudou Teologia. Em seis de julho de 1930, foi ordenado sacerdote. Feliz, voltou para o Brasil, onde os superiores o nomearam coordenador dos estudos no recém-fundado Ginásio Dom Bosco de Campo Grande. Apenas com trinta anos de idade, foi nomeado diretor da Casa Santa Teresa de Corumbá e, em 1937, diretor do Ginásio Municipal Dom Bosco de Campo Grande. Em 1941, foi diretor em Silvânia, Goiás; em seguida, diretor em Tupã, São Paulo; e novamente em Campo Grande, do Colégio Dom Bosco, até meados de 1949.

${ }^{5}$ Estrada de Ferro Noroeste do Brasil (NOB).

${ }^{6}$ Salesiano de Dom Bosco, nasceu em 3 de abril de 1921, na região de Castel d’Aiano, Bologna, região central da Itália. Teve seu primeiro contato com os salesianos em Bagnolo, no Piemonte, para onde foi enviado no fim de outubro de 1933. Chegou ao Brasil em 12 de outubro de 1937 e foi encaminhado para Cuiabá, MT, para iniciar o noviciado no ano seguinte. Permaneceu em Cuiabá no Seminário da Conceição para os dois anos de estudos filosóficos, de 1939 a 1940. 
para prática salesiana, fiquei dois anos no Seminário Diocesano aqui, eu gradeava a terra para plantar milho e arroz. Depois, em 1965, fomos para São Paulo, para Teologia, por quatro anos. Então, terminado lá, voltei para Coxipó da Ponte, MT, era um internato com 110 meninos - naquele tempo, todas as casas salesianas eram internatos, para os alunos do interior, porque na cidade era pouca gente; no Dom Bosco, havia 500 internos. E aífui para Coxipó, fiquei três anos lá, e a razão de eu estar lá era porque era músico, tocava a banda, dirigia a banda, tocava piano, essas coisas de fazer barulho no colégio. Assim, durante três anos, tivemos uma banda marcial que tocava no colégio; todas as casas tinham banda para ocupar os internos. Assim, em 1972, chegou o inspetor Geraldo Pompeu de Campos, o mineiro: "Pensei de mandar você para Sangradouro". E aí passei por Sangradouro, mas tive péssimas impressões, mandei uma carta de três páginas, portanto: "Não!". Veio a resposta do mineiro: "Sabia do seu parecer, sábado próximo te encontro lá". Assim começou minha experiência com os Xavante em Sangradouro, encarregado da roça, da mecânica, da serraria, toda essa parafernália, a Missão era autônoma naquele tempo, pouca coisa se encontrava fora, era necessário produzir o que nós e os índios comíamos. Então, entrei nesse desafio de trabalhar com os Xavante, produzir com os Xavante, e aí começaram a aparecer umas luzes, que nós tivemos de comandar o trabalho produtivo dos Xavante. Comecei progressivamente, os homens casados e as mulheres casadas, "Façam a roça de vocês", para que eu vou ter de fazer roça e dar comida para eles? Assim fomos diminuindo, no fim ficaram só uns 60 rapazes Xavante e as moças com as irmãs. E com eles tocamos a roça, meio mecanizada. Digo meio porque não tinha pneu, então tínhamos um pneu de ferro com garras, isso serviu; tinha um trator de esteira, mas a esteira era pesada demais, era um trator agrícola polonês, não tinha partida. Então, quando precisava andar, no tranco, na descida, na hora que o motorista soltava a embreagem voava até o escapamento na frente, mas funcionava. Assim começamos com uma produção sem perder colheita, só com os rapazes e as meninas, devido à empolgação e à responsabilidade. Fazia com eles experiências: "Aqui, o que dá melhor?", "Onde é melhor para plantar feijão?". Nesse diálogo, conseguimos produzir espantosamente mais, naturalmente, a colheita feita à mão. Depois de dois anos, como era muito revolucionário, voltei para Cuiabá. No seminário de Cuiabá, fiquei três anos

\footnotetext{
7 Padre Geraldo Pompeu de Campos nasceu na Itália na cidade de Castelnuovo d’Asti, Piemonte.
} 
lá, como administrador e professor. Daí, de Cuiabá, fui para Alto Araguaia, dois anos, 1977 e 1978, colégio internato, 150 internos, filhos de fazendeiros, mas a turma era boa! E o diretor era o Padre Afonso Savassa ${ }^{8}$, e a coisa era animada lá!

Entrevistadores: Como foi a preparação do Sr. para trabalhar junto aos povos indígenas?

Pe. Georg: Não havia nenhuma preparação, salesiano é para culto; agora, meu interesse era aprender a língua, mas o senso dos salesianos não era aprender a língua, e sim civilizar.

Agora, eu consegui ter muito prestígio com os Xavante, porque trabalhava com eles e animava no trabalho e, quando eles iam caçar, caçava com eles, dormia com eles no mato. Isso os empolgou: "Nele dá para confiar". Então, percebi justamente que a chave de toda a questão é conseguir a confiança dos índios para alcançar alguma coisa. Um ano e meio [atrás] não confiavam em mim, porque eu era branco, era explorador; e aí foi o conflito com os outros salesianos, eu era amigo dos índios, e não dos salesianos.

Em 1979, mudou o plano, o inspetor era o Padre Josef Winkler ${ }^{9}$. Ele me mandou para São Marcos. Primeiro, para reunir a comunidade e discutir os assuntos; segundo,

\footnotetext{
${ }^{8}$ Missionário redentorista, nasceu no Bairro da Cruz das Almas, em Tietê, SP, no dia 5 de março de 1951. Foi ordenado sacerdote no dia 25 de fevereiro de 1979. Em 1980, foi transferido para Aparecida, SP, para atuar como formador no Seminário Santo Afonso. Em 15 de maio de 1981, retornou a São João da Boa Vista, SP, como membro da Equipe Missionária. Em 1982, passou a colaborar no Santuário de Nossa Senhora do Perpétuo Socorro, até que, no dia 1 o de setembro de 1982, tornou-se reitor do Santuário. Três anos depois, em 1985, foi residir em Tietê, assumindo o cargo de reitor da Igreja de Santa Teresinha. Também foi nomeado superior da comunidade religiosa em 1985 e ficou no cargo até 1994. Ao deixar a função, continuou cuidando da Igreja de Santa Teresinha até 1997. No segundo semestre de 1997, passou a residir em Roma, na Itália, para os estudos de Especialização em Teologia Catequética. Também foi conselheiro provincial, atuou como reitor da Igreja de Santa Teresinha. Como seus últimos trabalhos em 2018, passou a integrar a comunidade iniciada no Santuário Bom Jesus de Pirapora, em São Paulo, e ali permaneceu por quase um ano, quando foi nomeado pároco da Paróquia Santuário São Geraldo Majela, em Sorocaba, SP, onde permaneceu até sua morte.

${ }_{9}^{9}$ Nascido no dia 13 de junho de 1935, na Alemanha, região de Sudetos, colonizada no século XII. Viveu parte de sua infância em uma simples casa no vilarejo chamado Lexen. De 1958 a 1960, estudou Filosofia em Campo Grande, MS. Dedicou parte de sua vida salesiana às cidades de Rondonópolis, MT; Alto Araguaia, MT; Campo Grande, MS; e Cuiabá, MT, tanto no Salesiano Santo Antonio (Coxipó) como no Colégio São Gonçalo e Paróquia São Gonçalo, onde atualmente é o vigário paroquial.
} 
administrar a casa; terceiro, "quatro a seis meses para aprender a língua Xavante". E não tinha nada escrito, não sabia de nada, que em 1976 já havia um convênio de ortografia da língua Xavante. Mais tarde, fui descobrindo algum documento desse encontro, para definir a ortografia Xavante, porque tinha o grupo $\mathrm{CIOL}$ (Chartered Institute of Linguists). Eles eram todos americanos e ingleses, escreviam o Xavante a partir do inglês. Do nosso lado, estava nosso Mestre Adalberto Heide ${ }^{10}$, alemão, que fez o seu sistema de grafia a partir do alemão, não do português. Então, nessa divergência de escrita Xavante, a Funai convidou os linguistas e teve, de 27 de junho a 3 de julho, o Encontro de Língua Xavante em São Marcos, em que foram definidos os elementos para todos escreverem a língua Xavante da mesma forma.

Entrevistadores: O Sr. comentou que foi para São Marcos para discutir algumas questões com eles. Quais eram essas questões?

Pe. Georg: A prática tradicional, agricultura para toda a aldeia. Imagine 1.000 pessoas, desde as crianças que semeavam até o pai que abria o buraco. Então, todas as idades estavam envolvidas na produção agrícola. Peguei esse sistema em andamento em São Marcos; eu devia comandar aquilo, mas a gente aprende com eles e, com isso, consegui. Depois, entrou em 1979 o grande projeto de desenvolvimento da Funai, para a produção de todas as áreas Xavante. Então, os Xavante confiavam em mim e, naturalmente, a Funai não confiava muito em mim. Era o tempo da ditadura militar. Mas esse projeto agrícola era unicamente plantar arroz em grande extensão; para isso, tínhamos da Missão e da Funai três tratores grandes e dois pequenos, tínhamos também três semeadeiras e uma colheitadeira grande. O meu papel era intermediar o ensino do uso e a manutenção do equipamento. Então, claro que em São Marcos nós tínhamos uma grande oficina mecânica. Havia cinco indígenas que eram mecânicos, eles faziam de tudo, até que um dia o Cacique, empolgado, viu que todos os Caciques tinham um Toyota reformado e veio me falar, solenemente: "Quero que o senhor faça reforma geral no meu Toyota". E eu disse: "Você sabe o que é que é isso?". Ele disse: "Sei, sei, sei". Então, começamos na segunda-feira, falei para o menino o que era e já tinha

\footnotetext{
${ }^{10}$ Nascido na Alemanha na cidade de Silésia, no ano de 1934, colaborou na elaboração de materiais cinematográficos do povo Xavante, importante contribuição para a memória e preservação do patrimônio imaterial, junto do Padre Giaccaria.
} 
visto o que o Toyota tinha. "Vamos desmanchar". Então começamos a desmanchar, um diferencial aqui, outro lá, começamos a desmanchar, fazer um levantamento do que precisava, quando, na hora do almoço, chegaram três velhos: "O Toyota está pronto?". E os jovens mostraram. "O Toyota está aqui, o diferencial está aqui", falaram os jovens, empolgados, e os velhos não acreditando no que estava acontecendo. Eles foram lá chorar com o velho Cacique: "O Georg acabou com o Toyota"; depois do almoço, ele veio com os três velhos e mais outros: "Padre, onde está o nosso Toyota?". E os jovens Xavante explicaram tudo como era. O Cacique disse: "Padre, não confio em você, eu pedi uma reforma geral e você acabou com o Toyota, você me decepcionou". Eu falei: "Eu vou fazer reforma de tudo, temos que arrumar tudo pra você ter um Toyota bom". O Cacique respondeu: "Você está prometendo, mas não acredito muito, não". Mas, depois, os jovens começaram a explicar a questão. O fato é que, em três meses, fizemos a reforma geral e, como também tinha aula de Geometria na escola do primeiro ao quarto ano, eu dava aula de Geometria; na classe, estavam todos os mecânicos, então uma geometria era medir a carroceria do carro, a largura, e esses meninos estudaram, e aí começamos a organizar também a carpintaria. Havia todos os equipamentos, mas os meninos trabalhavam, só que, entre parênteses, quando tinham as peças colocadas, as laterais da carroceria, as meninas iam atrás de lenha, e quando nós íamos embora, elas recolhiam as nossas madeiras. Era um trabalho... Mas conseguimos terminar o Toyota. Tinha solda elétrica, solda de oxigênio, tinha tudo.

Entrevistadores: Havia outros projetos da Missão?

Pe. Georg: Naquele tempo, só tinha a questão da escola e, no fim, em 1984, apareceu a questão: vamos aumentar o nível da escola para 8a série? Porque nós entendíamos muito bem que, com a escola aumentando a escolaridade, nós estávamos dando um passo rumo à civilização, ao mundo civilizado dos índios. E nós não queríamos dar essa iniciativa, porque nós não sabíamos o resultado disso. Mas, no fim, eles discutiram entre eles, conosco, também, e eles queriam estudar - e na própria língua. Como eu estava começando a trabalhar na língua Xavante, em 1982 já havia um dicionário e uma gramática, na aula já se fazia esse passo de trabalhar a escola "indigenamente", ao contrário de outros professores que davam aula em português e os índios não entendiam nada. 
Entrevistadores: Como foi a construção dessa gramática Xavante?

Pe. Georg: Bom, eu descobri depois as convenções da grafia Xavante do $\mathrm{ClOL}$, o Mestre Adalberto Heide não quis entregar as chaves da língua. Então, comecei a construir a gramática a partir da experiência e do diálogo com eles. Descobri que toda a língua Xavante também tem as dez categorias universais de substantivo, adjetivo, verbo, advérbio e tudo mais, e fui ordenando. A maior dificuldade Xavante é o verbo, além de muitas interferências fonéticas, de mudança fonética. Então, diante disso, a coisa era tremendamente complicada, mas os Xavante falavam isso naturalmente, então a referência são eles. Então eu tinha trabalhado, na aula discutíamos isso, e eles eram empolgados porque nunca tinham estudado a própria língua. E, com o prestígio mecânico e agricultor, tínhamos 500 hectares de arroz, somávamos tudo em uma harmonia de trabalho e estudo. Isso foi até 1986. Em 1986, chegou o inspetor José Marinoni11: "Vai para FUCMAT e escreve tudo que você sabe". E lá fui para o Colégio Dom Bosco, onde estou morando outra vez, e em 1987 escrevi o dicionário Xavante/Português; em 1988, a gramática; em 1989, o Português/Xavante. Naturalmente, tudo periodicamente, íamos a São Marcos e deixávamos [o material] com eles, e, como conheço os Xavante, fui com uma professora linguista, que não acreditava que ainda havia índios. Ela foi comigo para São Marcos, e eu disse: "Daqui a pouco vai ter criança para aula". E a criançada chegou toda gritando e brincando em Xavante, e ela: "Aqui não é Brasil, não". Então, depois de pedir ao professor que me cedesse com os alunos uma aula, distribuí o dicionário para cada um deles, porque meus alunos sabiam da minha metodologia, e eles tinham uma nitidez de analisar o texto e corrigi-lo. Eram rapazes de 14, 16 anos, mais ou menos. E Xavante tem isso, ele pega um negócio aqui e ele não escuta mais nada, com capacidade de abstrair todos os barulhos externos. Então, esse era o método de fazer as correções. A gramática ainda hoje é a mesma, o dicionário é o mesmo, era fundamental. Depois, o Padre Bartolomeo Giaccaria ${ }^{12}$ se animou de fazer algum texto didático, só que ele não

\footnotetext{
${ }^{11}$ De origem italiana, da cidade de Fenegrò. Possui vasta experiência na Educação Superior, tendo ocupado o cargo de Reitor da Universidade Católica Dom Bosco (UCDB) de 1993 a 2015. Após 5 anos, reassumiu a reitoria da Instituição.

12 Sacerdote salesiano, nasceu no dia 11 de setembro de 1932, em Chiusa di Pesio, Cúneo, Itália. Professou na Congregação Salesiana aos 16 de agosto de 1951. É graduado em Filosofia e está no Brasil desde 1954, tendo trabalhado em Sangradouro, São Marcos e Nova Xavantina, em Mato Grosso. A partir de 1957, começou a coletar os vários elementos linguísticos e gramaticais
} 
aprendeu a língua. Mas ele os fazia escreverem, só que a escrita era toda complicada, então tinha que passar uma peneira. Agora, típico é o livro "Meu mundo", que temos lá embaixo [na biblioteca], passou por três versões, até que, com os alunos do segundo grau, fizemos a afinação do português com o Xavante, porque não estava afinado. Afinamos esse livro para uma edição crítica. Então, mais ou menos, foi o começo do trabalho na língua Xavante. Naturalmente, depois chegou a Funai. Uma questão já foi conosco com a Funai em São Marcos, porque na agricultura só Xavante trabalha, nenhum externo, nem operador nem nada. Eu era o único de fora. E, nos outros postos da Funai, também havia o projeto, nenhum índio trabalhava, somente funcionários contratados. Até que o chefe de posto disse: "Nós temos que ver em São Marcos o que está acontecendo lá". E chegaram todos os chefes de posto em São Marcos, para examinar o trabalho que estava acontecendo. Tudo estava arrumado, tudo funcionava, o que não acontecia nos postos. Isso resultou em uma visita que mudou a perspectiva dos chefes de posto quanto à Funai. A Funai estava trabalhando para os índios sem os índios, o que colocou em crise todo o trabalho da Funai, que praticamente não fazia nenhum trabalho de promoção.

Entrevistadores: O Sr. cita o Pe. Rodolfo. Como foi a passagem dele junto ao povo Bororo?

Pe. Georg: O Rodolfo teve privilégio, pois não era músico, de ir logo para Meruri, MT, como jovem salesiano. Lá tinha o internato, para os de fora, todos os políticos na época, de Barra do Garças a Poxoréu, MT, toda a região estudava em Sangradouro e em Meruri. Naquele tempo, era uma escola de referência; internato, naturalmente. E assim Rodolfo esteve no internato em Meruri, como estudante, os três anos de prática. Então, Rodolfo trabalhou com os Bororo. Quando, em 1972, eu ia às Missões, Rodolfo passava em minha casa para irmos a Meruri - ele era motorista de caminhão, carregava as coisas, aí nós conversávamos também. Quando,

da língua Xavante e, em dezembro do mesmo ano, redigiu e publicou, em edição provisória e reduzida, um dicionário Xavante/Português (com mais de mil verbetes) com as primeiras noções da gramática Xavante. Em 1958, publicou para alunos da etnia Xavante a primeira edição da cartilha bilíngue (Xavante/Português), que, corrigida e ampliada, foi publicada em 1959, 1966, 1978 e 1980. De 1957 a 1980, realizou uma coletânea de artefatos da cultura Xavante, que atualmente constituem a coleção do Museu das Culturas Dom Bosco. 
em 1973, começou a demarcação da terra de Sangradouro, começou uma tensão tremenda com o mundo de fora. Começou porque a terra que não tinha ninguém, de repente, tinha dono. Eu estava em Sangradouro, foi a primeira terra demarcada, eu me envolvi um pouco na demarcação, depois os salesianos me falaram: "Você fique longe, senão eles te matam". Dito e feito, um dia um Xavante veio correndo, uns 15 pistoleiros a cavalo foram atrás de mim na demarcação, só que não estava na demarcação. Então, esse era o clima da época. Em São Marcos, o clima ficou mais tenso em 1974, 1975, porque, quando foi para demarcar lá, havia poderosos políticos. Eles eram os donos de tudo, eles eram pistoleiros, e quem passava no caminho levava bala. Então, diante disso, em São Marcos a coisa começou a esquentar. Os salesianos, pelos Xavante, espionavam os movimentos nas fazendas vizinhas, assim, os salesianos perceberam que estavam organizando alguma coisa pesada. Mas acontece que os salesianos, todos italianos, apelaram para o consulado italiano, que naturalmente acionou a Polícia Federal de Cuiabá. Me contaram que receberam ordem de desmanchar um eventual ataque contra a Missão, e cinco agentes, de metralhadora, de madrugada, chegaram à propriedade do fazendeiro, e 30 homens para atacar São Marcos. Eles vasculharam toda a casa e não acharam nada. No fim, um agente federal disse "Estou com sede", pegou na geladeira e puxou: foram caindo armas que estavam atrás da geladeira. Prenderam todo mundo e levaram os 30 homens presos para Barra do Garças. Com isso, o ataque a São Marcos foi abafado. Rodolfo estava em Meruri, e lá a coisa era mais delicada, porque São Marcos, Sangradouro, eram reservas criadas pelo governo e indenizadas. E Meruri, como terra ancestral, não tinha nenhuma indenização em vista, e isso esquentou o clima em toda a região do povoado de General Carneiro até Barra do Garças, tudo estava tenso. Padre Rodolfo, fazendo as andanças pela terra Bororo, encontrava frequentemente uma invasão, gente que derrubava cerca. Os Bororo, com o Rodolfo, começaram a protestar, mas todo mundo achava que era o Rodolfo o mandante, então o nome do Rodolfo tornou-se muito malvisto na região. Bom, em 1976, a coisa começou a piorar, estava prevista também a demarcação em Meruri, e no dia 13 de julho estávamos com Rodolfo em Cuiabá, em uma festa dos salesianos. Rodolfo estava branco e amarelo, apavorado, disse: "Não sei o que vai acontecer". Isso foi em um domingo, na terça-feira teve o famoso assalto, vieram caminhões e carros, com umas 30 pessoas instruídas para a matança do Rodolfo. Mais 40 outros, arrebanhados, para fazer volume, mas que não sabiam das intenções. Chegaram a 
Meruri, pediram para falar com o Padre Rodolfo e falaram "Não, ele não está. Está na roça". Só encontraram o Padre Gonçalo Alberto Ochoa Camargo ${ }^{13}$, então os Bororo foram na roça chamar o Padre Rodolfo. E o Rodolfo chegou, cumprimentou todo mundo, abriu o escritório dele, recebeu todo mundo, escreveu o nome de cada um, tamanho da terra, registrou tudo, então parecia que estava pacificamente resolvido. Umas duas horas depois, o Rodolfo começou a se despedir deles. Mas o famoso João Mineiro disse: "Não vai ficar assim, você nos levou na conversa, isso não produz nada". Era um dos fazendeiros. Todos ali, naturalmente, estavam armados. Mas não sabíamos que um deles era um pistoleiro contratado para matar o Padre. De repente, começou a confusão, tiros de cá, e os Bororo também, mas eram poucos Bororo porque eles estavam demarcando a terra, e o Rodolfo estava no meio da praça de Meruri e de repente levou um tiro "aqui", levantou a mão e mandou parar, aí veio outro tiro, e outro tiro. Os Bororo também, o Simão Koge Ekudugodu ${ }^{14}$ estava na frente do Padre, quando ele viu que queriam matar o Padre, ele se colocou na frente, e ele levou tiro e caiu, por isso morreu com Rodolfo. Outro que também morreu, um dos atacantes, um jovem, começou a dar tiro, um Bororo mirou nele, mas eles recolheram e levaram embora, morreu no caminho. Enquanto isso, eles tinham previamente cortado todas as linhas telegráficas, para não comunicar o fato, mas o que eles não sabiam é que dias antes nós tínhamos instalado o rádio amador em nossas Missões, com todas as casas salesianas. E às 11 h30 nós entrávamos, às $18 \mathrm{~h}$ e às $7 \mathrm{~h}$. Foi uma irmã que pegou e chamou Campo Grande. Na época, ainda tinha o comando da Polícia Federal aqui, e o delegado era uma pessoa sensata, determinou de imediato ao agente de Barra do Garças para ir a Meruri. Só que esse agente era secreto da polícia, então a polícia confiava tudo a ele, não sabiam que era federal, então foi dito: “É uma ordem superior, agora nós

\footnotetext{
${ }^{13}$ Sacerdote salesiano, natural de Toca, Colômbia, nasceu aos 6 de dezembro de 1929. Professou na Congregação Salesiana aos 24 de janeiro de 1949. Em 1958, veio para o Brasil incorporando-se à Missão Salesiana de Mato Grosso, estabelecendo-se no Colégio Dom Bosco de Campo Grande. Em 1960, foi destinado à Colônia Indígena de Meruri para o trabalho missionário com o povo Bororo. Atualmente, Pe. Ochoa continua trabalhando na Aldeia Meruri, onde, somando idas e vindas, chega ao total de 48 anos. Integrou-se profundamente na vida do povo Bororo, dominando a cultura e a língua dessa etnia. Desenvolveu, com a comunidade salesiana, inúmeros trabalhos em favor desse povo no âmbito da religião, educação, direitos, promoção do autossustento e da cultura.

${ }^{14}$ Indígena da etnia Boe Bororo, Simão Koge Ekudugodu. Morto em conflito em 1976, em Meruri, MT.
} 
vamos para Meruri". Logo depois do almoço, receberam ordem para ir a Meruri, só que os atacantes já haviam pulverizado. Então, com isso, Rodolfo morreu em 15 de julho de 1976. Aconteceu com ele, se nós estivéssemos lá, ia ser a mesma coisa, não tinha como. O assunto era que, como mataram o Padre, mataram liderança e acabou o problema. Só que lá não acabou, porque lá tinha em São Marcos o famoso Mestre Salvador. Ele, sabendo das coisas em São Marcos, chegou com um grupo Xavante. Quando os Bororo pensaram em parar com a demarcação, chegaram os Xavante, então a terra de Meruri foi de imediato concluída, devido à atuação dos Xavante junto aos agrimensores, assim ela foi demarcada.

Entrevistadores: Como o Sr. começou o trabalho na UCDB, no Centro de Documentação Indígena (CDI)?

Pe. Georg: Já falei para vocês que fui à torre do Dom Bosco ${ }^{15}$ (FUCMAT), comecei com aquela máquina IBM, consegui formatar o texto e colocá-lo para impressão. Como tinha um administrador muito categórico, José Luiz, que dizia "Produza que nós publicamos", era produzir para mandar publicar. Depois, fui em 1989 para o Paulo VI ${ }^{16}$; em 1992, fui para inspetoria e lá saí do quartinho de 3 X4 e comecei a organizar o trabalho de documentação. Só que estava sozinho; de repente, surgiu uma pessoa, um estudante da UCDB sentou-se ao meu lado durante as aulas, fez uma pesquisa e descobriu que, a pedido do Pe. João Bosco, eu criei o curso de língua Xavante por correspondência, quatro páginas, de 15 a 20 dias mandava para os missionários para eles aprenderem Xavante, porque Padre João Bosco dizia: "Se você ensinar mandando um livro, ninguém aprende, então faz por folheto". Só que esse moço da UCDB soltou a coisa por um jornal, choveu assinatura, tinham 500 para o curso de língua Xavante. Não dei conta mesmo, tenho ainda a caixa com os endereços lá, e pedi uma famosa colaboradora, que já tinha sido voluntária em São Marcos, Mariza Etelvina Rosa Irala ${ }^{17}$, que era folheira ${ }^{18}$ da UCDB. Pedi a Mariza como auxiliar, foi autorizado e até hoje ela está conosco.

\footnotetext{
${ }^{15}$ Espaço físico situado nas dependências do Colégio Dom Bosco em Campo Grande, MS.

${ }^{16}$ Seminário Salesiano em Campo Grande, MS.

${ }^{17}$ Mariza Etelvina Rosa Irala atualmente trabalha com a documentação no CDI, localizado na Universidade Católica Dom Bosco.

${ }^{18}$ Funcionária que passava de sala em sala recolhendo assinatura dos estudantes para lançamento de presença nas aulas.
} 
Entrevistadores: Como foi inserida a temática indígena na criação da UCDB?

Pe. Georg: A UCDB, para se consolidar como universidade, precisava apresentar um produto de pesquisa. Podia apresentar para o MEC pesquisas antropológicas, um museu, a enciclopédia Bororo, que foi publicada em 1961 e 1962, então, o assunto indígena era a pesquisa da UCDB. Portanto a minha pesquisa com a língua Xavante, a cultura, entrou no embalo aí, foi colocado nesse contexto da universidade, como pesquisa da universidade. E, uma vez que foi criada a universidade, o então inspetor Padre Afonso de Castro $^{19}$, de imediato, decretou minha transferência do Colégio Dom Bosco para a UCDB. Fui colocado lá no espaço em que foi constituído o Centro de Documentação Indígena, onde estamos até hoje ainda, e com pequenos projetos para a Alemanha fui adquirindo equipamento, as prateleiras e tudo que temos lá.

Entrevistadores: Como foi a participação do Sr. no CIMI?

Pe. Georg: Veja bem, o Conselho Indigenista Missionário (CIMI) foi fundado em 1972, no Encontro de Formação de Missionários em São Paulo. Nesse encontro, estava o Padre Ângelo Jayme Venturelli20, como antropólogo; estava o estudante Padre Rodolfo, recém-chegado da Alemanha. Rodolfo endossou totalmente a questão do CIMI. Depois, entrou Dom Tomás Balduino, Bispo de Porto Velho, depois Goiás Velho, foi 28 anos Bispo piloto, ele pilotava o "teco-teco" para visitar o interior de Goiás. E o Rodolfo, depois, para a questão do CIMI, andava com ele até Manaus, onde tinha um grupo, [e] até Mato Grosso do Sul, onde tinha um grupo desde 1978, [com] o Antônio. Então, Rodolfo entrou logo na coordenação nacional do CIMI, e ele era empolgado, animado. Como era diretor de Meruri, era uma figura relevante no CIMI, embora os agentes do CIMI tivessem outras

\footnotetext{
${ }^{19}$ Sacerdote salesiano desde 1970, nasceu em Nova Aurora, GO, em 26 de julho de 1942. Foi professor nos cursos de Filosofia e Letras, diretor de faculdade e pró-reitor acadêmico da Universidade Católica Dom Bosco, em Campo Grande. Um dos seus trabalhos mais importantes tem sido o resgate do carisma salesiano e a releitura do sistema educativo de Dom Bosco para hoje.

20 Nasceu em 24 de fevereiro de 1916 em Sanremo, Itália. Passou sua vida na cidade de Campo Grande, exerceu todas as funções de administrador, cientista, capelão e, principalmente, de sacerdote salesiano. Contribuiu com as atividades em prol da educação, da ciência e da cultura para Mato Grosso. Missionário desde a juventude, traduziu seu apostolado em pesquisa científica, em ações que beneficiaram tantas pessoas e a cultura. Sua vida esteve intimamente associada à pesquisa científica da Antropologia Cultural, ao ensino superior no Estado de Mato Grosso do Sul e à atuação da Congregação neste vasto território denominado Mato Grosso.
} 
perspectivas, porque indivíduo é indivíduo e porque padre egresso e freira egressa, mas com ideal indigenista, não vão se afinar com os ideais religiosos. Antônio Brand $^{21}$ veio para cá como agente da Operação Anchieta (OPAN), mas, quando a OPAN, por própria iniciativa, teve que ver se concordava, se aderia ao CIMI ou se ficava independente, a OPAN decidiu ficar independente do CIMI. Nessa época, vários como o Antônio passaram a ser agentes do CIMI, porque entendiam que a ação e a proposta do CIMI eram bastante acertadas.

Antônio Brand começou a entrar no CIMI em 1978, na Vila São Pedro, Indápolis, e por aí a gente conhecia, quando, em 1986, participei de uma assembleia do CIMI e encontrei com Antônio também; eu me tornei uma figura mais familiar do ambiente do grupo do Antônio, que era coordenador do CIMI. Naqueles anos 1980, foi significativo que Antônio, por 8 anos, fosse o coordenador, secretário do CIMI, em que ele articulou as forças simpáticas aos povos indígenas para que essa questão fosse incluída na Constituição de 1988. Depois, o Antônio pediu baixa do CIMI, outros assumiram o comando, e ele voltou para Porto Alegre, estudou História, fez mestrado e doutorado, e então ele se apresentou. Fui eu que o recebi aqui, já doutor em História, depois do trabalho com o CIMI, para entrar na UCDB.

Entrevistadores: Antônio Brand foi convidado por algum de vocês?

Pe. Georg: Eu estava no meio, mas eu falei para o Padre Afonso de Castro ${ }^{22}$ "Contrata já", porque a forma [de atuação] do Antônio pela constituinte ${ }^{23}$ foi

${ }^{21}$ O professor Antônio Jacó Brand nasceu em Dom Diogo, RS, atual município de São José do Sul, RS, no dia 13 de janeiro de 1949. Foi para o seminário aos doze anos de idade e saiu quando foi convidado a trabalhar com a questão indígena na OPAN. Concluiu a graduação de História na Unisinos, em 1977, na cidade de São Leopoldo, RS, e se mudou para Dourados, MS, em 1978, onde fundou o Conselho Indigenista Missionário (CIMI) em Mato Grosso do Sul. Em 1983, mudou-se para Brasília ao ser eleito Secretário Nacional do CIMI, tendo exercido a função por oito anos. Após esse tempo, concluiu seu mestrado em 1993 e o doutorado em 1998, na PUC de Porto Alegre, RS. Em 1996, passou a fazer parte do grupo de docentes da UCDB, em Campo Grande, MS, onde também iniciou seu trabalho no NEPPI.

${ }^{22}$ Graduado em Letras, Filosofia, Teologia e Pedagogia, mestre em Letras pela UNB e doutor em Teoria Literária e Literatura Comparada pela UNESP de Assis, SP. Sacerdote salesiano de Dom Bosco desde 1970, foi professor, pró-reitor da Universidade Católica Dom Bosco e diretor do Centro Universitário Unisalesiano de Lins e Araçatuba (SP). Disponível em: http://www.missaosalesiana.org.br/padre-afonso-de-castro-lanca-livro-sobre-nossa-senhora-auxiliadora/

${ }^{23}$ Referindo-se às mobilizações em prol dos direitos indígenas na Assembleia Nacional Constituinte para elaboração da Constituição Federal de 1988. 
muito importante. Na verdade, o NEPPI já tinha surgido um pouco antes, com a professora leda Marques de Carvalho ${ }^{24}$, para dar consistência à pesquisa indígena e à atuação na UCDB.

Entrevistadores: Como foi a participação do Sr. na criação do NEPPI?

Pe. Georg: Na época, como eu trabalhava na questão, estava presente ocasionalmente, mas o NEPPI não era amarrado em pessoas, era um movimento mais amplo, e a professora leda era esse tipo fantástico de somar interesses. Quando o Antônio chegou, ela agradeceu, ela não se afastou, mas não esteve mais ativamente agindo, já que o Antônio assumia.

Agora, sobre o Antônio, eu posso dizer o seguinte, o Antônio era um vulcão. Não sei quantas iniciativas tinha na cabeça dele; enquanto fazia uma e fazia um projeto, conseguia chamar gente para outro projeto. Era esse movimento amplo de projetos a favor da causa indígena. Nisso, Antônio era artista.

Entrevistadores: Como é hoje a relação dos salesianos com os povos indígenas?

Pe. Georg: Vamos dizer a realidade: para os salesianos, a questão indígena é polinômio, tem uns a favor e uns não tão simpáticos. Por isso que hoje, com Padre Gildásio Mendes dos Santos ${ }^{25}$, levamos os jovens para tirar um mês de férias para entrar em contato com a realidade. Nos anos 1920, íamos para Campo Grande para o Instituto Pestalozzi - como eles praticamente fracassaram e entregaram o prédio para os salesianos, lá começou a presença salesiana como colégio. Foi para Corumbá, para Ponta Porã, para Três Lagoas, e os padres itinerantes permeavam tudo. O Padre Hipólito Chovelon, depois de ir para Corumbá, ia a cavalo para Porto Murtinho, e lá para frente até Ponta Porã, voltava e ia até Rio Verde e Coxim. Eram os padres itinerantes. Padre João Crippa ${ }^{26}$ era outro desses. Tinha sempre gente simpática ao povo simples e também aos indígenas. Mato Grosso do Sul não teve um trabalho à maneira de Mato Grosso, e alguns querem ver isso hoje,

\footnotetext{
24 Professora na UCDB e coordenadora no NEPPI nos anos de 1997 e 1998.

25 Nascido em 1963, em Conceição da Barra, ES. Atualmente, é inspetor da Missão Salesiana de Belo Horizonte (2020-2026).

${ }^{26}$ Nascido em Asso, na Itália, em 1861, foi Fundador da Igreja Matriz São José.
} 
mas hoje a realidade é outra aqui. Então, o Padre Gildásio entende que o trabalho do NEPPI, com os diversos projetos, é a nova maneira do trabalho indígena de Mato Grosso do Sul. E, como é para nós, claro, os projetos do NEPPI em Caarapó são projetos exemplares para as outras aldeias, e é para se espantar vendo em Caarapó a horta escolar, a origem da horta pelo projeto escola, 900 alunos, e mal e mal chegava a 100 alunos quando os pais pediram, então, é um projeto que respondeu às expectativas dos Guarani, por isso eles assumiram como próprio, para o espanto de muitos projetos Bororo e Xavante. Os Guarani assumiram a horta escolar, o reflorestamento e muitas outras coisas lá. Nisso o Antônio teve uma boa visão de não criar dependência, e com toda a equipe.

Muitos salesianos gostariam de fazer um projeto tipo Mato Grosso, mas não sabem como começar. O inspetor entende que não é desse jeito, que hoje temos que ter outro tipo de presença, esse tipo de presença, que o Pe. Gildásio Mendes dos Santos muito estima, é o projeto Caarapó, presença simbólica, porque os Guarani são tantos, tão dispersos, que não dá para fazer um projeto abrangente, a não ser esse como exemplar, que está se estendendo para outras frentes. Uma outra questão que surge aí é o modo como trabalhar com os Guarani. Os salesianos, querendo ou não, são padres pregadores, batizadores e tudo mais; agora, desde que as Lauritas foram ao Paraguai e já pela formação que tivemos recentemente, entendemos que não dá para ser batizador entre os Guarani. No Paraguai, eu fiz a experiência com as irmãs, eles estimaram imensamente minha presença como padre que trabalha e não prega, e com isso um dia me levaram a um piseiro pelo mato; de repente, estávamos na frente de um templo Guarani, de palha, todo redondo. Tenho uma fotografia dele, lá a mulher nos levou para dentro, mandou fazer todas as reverências, apresentaram todos os objetos religiosos, então entenderam que nós não somos os tais batizadores, somos os amigos deles.

Entrevistadores: E o trabalho que o Sr. está realizando hoje?

Pe. Georg: Um dos grandes trabalhos agora é produzir, divulgar os livros já produzidos, para os Xavante e Bororo. Para os Bororo, é o Pe. Uchoa que está na Missão agora, e tem o Mestre Mário, que é também um batalhador, ele também produz. Para os Xavante, temos vários, uns 30 e tantos exemplares de livros diferentes, livros didáticos de diferentes tipos, então é multiplicar esse material e colocá-lo nas escolas. O ideal seria ter uma verba para fazer 3 ou 4 mil exemplares de cada tipo. 
Então, hoje vejo nosso trabalho a favor dos indígenas e a pedido deles. Nós temos o grande desafio dos acadêmicos indígenas, é um grande desafio formá-los para que eles assumam a liderança das escolas e das iniciativas nas aldeias. Penso que, nesse sentido, vale a pena investir de todos os modos em acompanhar, dialogar, formando, assim, os indígenas, acadêmicos da UCDB e das outras universidades que temos. Acho que é nisso que vale a pena investir.

\section{Sobre os autores:}

Eva Maria Luiz Ferreira: Mestre em História pela Universidade Federal da Grande Dourados (UFGD). Docente da Universidade Católica Dom Bosco (UCDB). Pesquisadora do Núcleo de Estudos e Pesquisas das Populações Indígenas (NEPPI/ UCDB). E-mail: evam@ucdb.br, Orcid: http://orcid.org/0000-0002-7792-6253

José Francisco Sarmento Nogueira: Doutor em Educação pela Universidade Católica Dom Bosco (UCDB). Docente do curso de Design e Filosofia e professor colaborador do programa de Pós-Graduação Stricto Sensu: Mestrado e Doutorado em Psicologia da UCDB. Desenvolve trabalhos de Ensino, Pesquisa e Extensão no Núcleo de Estudos e Pesquisas das Populações Indígenas (NEPPI/UCDB). Vem atuando em projetos com os povos Kaiowá e Guarani no estado de Mato Grosso do Sul. Desenvolve trabalhos de pesquisa que discutem a questão da identidade cultural e tem se dedicado a pesquisar sobre a cultura material de povos originários, a partir do Etnodesign. E-mail: josefsarmento@gmail.com, Orcid: https://orcid.org/0000-0001-5956-5602

Leandro Skowronski: Engenheiro Agrônomo, com Mestrado em Fitotecnia. Professor do curso de graduação em Agronomia Universidade Católica Dom Bosco (UCDB), e integra o Núcleo de Estudos e Pesquisas das Populações Indígenas (NEPPI/UCDB. No NEPPI, vem desenvolvendo trabalhos de ensino, pesquisa e extensão com os povos Kaiowá e Guarani do estado de Mato Grosso do Sul, nas temáticas da agroecologia e meio ambiente. E-mail: Isk@ucdb.br, Orcid: https://orcid.org/0000-0001-7725-0700

Lenir Gomes Ximenes: Doutora em História pela Universidade Federal da Grande Dourados (UFGD). Docente da Universidade Católica Dom Bosco (UCDB). Pesquisadora do Núcleo de Estudos e Pesquisas das Populações Indígenas (NEPPI/UCDB). E-mail: lenir_gximenes@hotmail.com, Orcid: http://orcid.org/0000-0003-1374-2997

Recebido em 20 de fevereiro de 2020

Aprovado para publicação em 6 de abril de 2020 